\title{
Discourse of Mobbing in Turkish Press
}

Assoc. Prof. Dr. Ece Karadoğan Doruk

\begin{abstract}
Mobbing (Psychological violence in working place) has been researched especially by the scientists making researches in organizational communication for last 20-25 years. In Turkey, mobbing concept is a newer research field. In this study, how the news regarding mobbing has been given in Turkish press will be analyzed with Van Dijk's discourse analysis.
\end{abstract}

How the news regarding mobbing has taken place in Turkish press will be analyzed by applying Van Dijk's discourse analysis. From the year of 1997 when the news related to the mobbing appeared to today, what kinds of differences happened in news discourses especially with taking place of mobbing in Turkish Criminal Law, will be analyzed.

Keywords: Mobbing, working place, victim

The working concept is to use human's physical and mental powers for a determined aim in a planned manner. Nowadays almost the most important one of the personal prestige criteria is regarded as the success in working life. Therefore, the working life is leading in basic communal institutions to have an important role and place in the community and reflect existing potential. The working life has an important place in human life, because one third of the human life passes by working and in this activity the individual sustains the continuity of his/her life. By working the individual not only earns monetary gain, but also has moral gains with the issues such as becoming happy, successful and satisfied from the work s/he accomplishes. Due to the fact that the working life affects the individual's relations with the community and communal position, the encountered problems affect the individual's whole life negatively.

Mobbing (Psychological violence in working place) is not a very new concept in working life. It is an issue which is always existing in the communal life and working life, but do not come into prominence due to the prevalence of other violence types. Mobbing, which is one of the hidden dangers of working life, is evaluated within the concept of 'violence' which goes all lengths to reach its aim in terms of the individuals exposed to this condition and its formation manner. There are many dimensions of violence; it extends from physical violence to sexual 
violence and verbal violence, from there to the psychological violence applied to the targeted individual. All of these violence types also take place in working life as in communal life. In recent years, especially psychological violence has become one of the most important encountered problems in working life.

Mobbing, which is composed of malicious activities aiming at expelling an individual or a group from working place through applying unfair accusation, general harassment, humiliation, abasement, emotional torture and psycho-terror, is a process having various stages and spreading at least to three and six-month period. Among the reasons of mobbing (Psychological violence) profit/return law is mentioned at most. The reasons such as change of working place condition in the course of time, seeking high productivity and competition, autonomy increase, increase the pressure on the workers in the context of unemployment. As a result of this pressure in which there is a full damnification for the worker regardless of public or private sector, the decreasing of individual's productivity in the working place is inevitable.

The intimidation behaviors in the organization has been observed as horizontal, downwards and upwards and arisen from the power relations in the organization. Whatever the direction of these activities realized in harming and despotic manners are in the organization, as a result they affect the workers negatively, make them resign from their duties and reach to the levels affecting their health. As a result of this pressure, the worker has to cope with the mental problems resulting with being dismissed and hard to be repaired.

When Swedish scientist Leymann defined the mobbing behaviors in the year of 1984 for the first time, he emphasized that these behaviours were a type of working place terror. Leymann not only expressed the existence of mobbing behaviour in the working place, but also emphasized the special attributions of the behaviour, its emergence way, the person who were affected from the applied violence at most and its possible psychological consequences.

In terms of our country's workers the situation is a little bit difficult. Because of the fact that the issue of requesting help is just a new understanding for Turkish community in psychological terms, medical advice is not mostly sought. It is possible to say that this requirement is solved with strong family ties in our community. In our country, there are not 
"support and rehabilitation centers for intimidation" like in the developed countries giving importance to physical and mental health of workers in their working place environments. Therefore, when it is considered that the individuals, who are suffered from the intimidation process and do not have families, can not get family supports, the situation is also a substantially difficult process for these sufferers. In our country, the attentions of neither academic and business environments nor the professional bodies have been attracted to the intimidation process. In fact, similar problems are encountered in many working places and increase more in economical crisis situations. This process threatens all workers in a manner which is as serious as not being ignored.

The researches regarding physiological violence are extensively made in Europe. Although it is limited, some researches have been made in this issue for the last 7-8 years in our country. The determination of the dimensions of the problem is important in terms of increasing the sensitivity of workers in this issue and ensuring that the institutions and related organizations take precautions regarding the issue. Raising awareness of the workers in mobbing issue and familiarity with the issue are possible with the fact that media, especially the printed press gives places to the mobbing news. As of when the news related to the mobbing appeared in Turkish press, with which discourses these news were given and the news' points of view to the issue are the starting points of this study.

How the news regarding mobbing has taken place in Turkish press will be analyzed by applying the content analysis method. From the year of 1997 when the news related to the mobbing appeared to today, what kinds of differences happened in news discourses especially with taking place of mobbing in Turkish Criminal Law, will be analyzed.

\section{What is Mobbing?}

The word 'mob' which is derived from the words 'mobile vulgus' meaning, 'fickle crowd' in Latin, means disorderly crowd or gang committing illegal violence. And mobbing means psychological violence, siege, harassment, disturbance or distress (Tinaz, 2006: 7). According to the definition asserted by Leymann, mobbing is psycho-terror and its reason can vary from thinking and belief differences to jealousy and sexual discrimination (Leymann, 1990: 119). While defining the mobbing behaviors in Sweden in 1984, Leymann emphasized that; these behaviors are some sort of workplace terror. This terror includes unethical 
communication and hostile acts directed by a person or a group to a single person (Leymann, 1996: 166). "Leymann did not only identify the presence of mobbing behavior in the workplace, he also highlighted the special qualities of this behavior, how it emerges, people to be most affected from the violence committed and psychological results that may arise" (T1naz, 2006: 11).

Leymann defines mobbing as "a psychological terror occurring as a result of hostile and unethical communication directed by one or more individuals toward one individual in a systematic manner that could be committed because of a discord in thoughts or beliefs, jealousy or sexual discrimination and other similar reasons" (Leymann, 2009). According to Davenport et al., mobbing is an emotional assault and it is defined as: "It begins when an individual becomes the target of disrespectful and harmful behavior. Through innuendo, rumors, and public discrediting, a hostile environment is created in which one individual gathers others to willingly, or unwillingly, participate in continuous malevolent actions to force a person out of the workplace" (Davenport et al., 2003: 15). According to Tutar, mobbing includes all maltreatment, threats, violence and humiliating behaviors exhibited systematically by seniors, juniors or equals of employees (Tutar, 2004: 11). From Baykal's point of view, mobbing consists of unfavorable behaviors aiming at a certain person in workplace and continuing for a long time in systematic manner (2005: 7). And Çobanoğlu (2005: 21-22) describes mobbing as making employees leave their works by employing systematic pressures on them and eliminating their performance and strength through unethical approaches.

We can define mobbing in communication process within the frame of its daily usage as acting in a humiliating way to a person, accusing the same person with being maladaptive, isolating that person in working life, intimidating the individual by exhibiting implications and exclusionary attitudes and forcing the individual to quit the job. As one can se,, many negative qualifications are used to explain mobbing concept.

"But the most desperate aspect mobbing process can turn into for the individual experiencing it is, not parting ways with the workplace despite all the insults and abuses to the mobbing victim and continuing to work there in spite of all the ostracizing applications and misconducts directed towards this individual"(Köse, 2006). Mobbing is an emotional assault. 
It begins when an individual working in a workplace becomes the target of a disrespectful and harmful behavior. The actions directed at the individual turn into terrifying behaviors and open abuses.

The term "mobbing" is used in various ways in Turkish literature. With the usage of the word "mobbing" becoming extensive in the course of time, its popularity in the sense of recognition increased. While its equivalent in Turkish is attacking, abusing, intimidation, "psychological terror", "psychological violence", "psychological intimidation", "psychological harassment" terms were introduced in the literature in order to distinguish it from brute violence. It is more suitable to use the word "harassment", considering its legal aspect and taking into consideration that; it defines the severity of the fact in question more accurately. It is useful to define it as "psychological harassment", since the mentioned harassment includes some assaults on the psychological integrity of the individual” (Güngör, 2008: 8).

"The common ground of all the results of the researches conducted at an international level reveals that; psychological harassment victims are more in number compared to other violence and harassment victims" (Tinaz, 2006: 2). As the studies on psychological harassment which negatively affects the personal and organizational communication and harms the psychological and somatic health of the addressed individual, not only in working life but also in every field of social life, increase; it will be possible to create awareness and try to find solutions to deal with this.

"Psychological harassment is in fact not a brand new term in working life. The leading motive for discussions about it at such an extent is that; since it has diminished both due to personal developments of individuals and also regulations including penal sanctions for other types of violence, the phenomenon of psychological harassment has come into prominence" (Güngör, 2008: 2). But legal arrangements on psychological harassment are not completely effective at present.

Researches about psychological harassment are generally conducted in Europe. Studies related to this issue are being carried out in the last 7-8 years in our country. Assessment of the aspects of the problem is of importance both in terms of increasing the sensitivity of 
employees about this matter and also in terms of making relevant bodies and organizations take some precautions with regard to this problem.

By creating awareness about the phenomenon of psychological harassment, social virtues like the sense of belonging, confidence factor, honesty, knowledge sharing, cooperation and coordinate working, which constitute the basic foundation of interpersonal and organizational communication, will positively affect principles like empathy, sympathy, assistance and solidarity among individuals and improve labor success.

The Process of Mobbing (Psychological Harassment)

In our day, mobbing is a case occurring in all cultures and workplaces regardless of sex and hierarchy. Therefore, everyone can be subjected mobbing. An individual that showed a significant success, gained the appreciation of his/her chief or directly the management or got praised by a customer can be easily envied by his/her colleagues. Any trick can be played on the individual, there may be rumors and his/her working may be sabotaged. In the beginning, as a result of the organizational psychological violence that developed as the hostility of a person or more to an individual, the victim firstly gets alienated from himself/herself and then his/her environment. This process begins with indifference to work, weariness, intimidation and decrease in performance and the individual can even resign from his/her work. There occurs a decrease in the job satisfaction and loyalty to organization. In the individuals injured by mobbing, some behavioral and ideological changes like sleeplessness, anorexia, depression, distress, anxiety, inactivity, weeping fits, forgetfulness, sensitiveness, peevishness, taciturnity, loss of the joy of living and not getting satisfied with the things loved before can be observed. And in cases where violence and harassment is experiences intensively, we may witness suicidal thoughts in the mobbing victim. (Çobanoğlu, 2005)

The effects seen in the first stage of intimidation process witnessed in victims are primarily crying without a reason, sleep disorders, peevishness and difficulty in concentrating. In the second stage, indications like hypertension, gastric complaints, depression unwillingness to go workplace and being late to work are added to the indications in the first stage. And in the third stage, depression becomes more acute and a panic attack and anxiety develops. Accidents and inclination towards suicide are mostly seen in the last stage of intimidation process (Namie and Namie, 2000: 63). 
In order to understand the process of mobbing, firstly the behaviors, that are witnessed in the working place and that lead to mobbing, should be identified. While some of these behaviors can be considered completely negative, some of them can also emerge as normal interaction behaviors. Such behaviors can be tolerated for once or the individuals acting that way can be comprehended supposing they are having a rainy day.

All mobbing cases do not necessarily include all of these behavioral signs. But repetition of these behaviors deliberately and continuously leads to mobbing and as a result, alienation of the individual from working life. While a behavior included in this list can create a problem for an individual, it may not pose any problem to another individual. If an individual considers that; he/she is disturbed and harmed from these behaviors, this behavior turns into a problem and becomes a mobbing behavior. (Tinaz, 2006: 49)

Behavioral Signs of Mobbing: (Tinaz, 2006: 50)

- Personal belongings of the individual in the workplace like telephone, computer and lamp are lost or out of order all of a sudden. They are not replaced.

- The discussions with work mates happen more than ever.

- A person smoking very much is placed to the desk next to the individual, despite knowing that the individual is disturbed much from the smell and the smoke of cigarettes.

- Conversations are immediately stopped when the individual goes into the office of others, and the subject is changed.

- The individual is not informed about important developments and news.

- Various rumors are spread behind the individual's back and people backbite the individual.

- The individual is given tasks well below his/her capability and skills or not within his/her area of expertise.

- The individual feels that; every movement of him/her is closely followed.

- The individual's entrance and departure from work, telephone conversations, and the time spend in tea or coffee breaks are controlled in detail.

- The individual is continuously criticized or despised by others.

- The individual cannot get response to his/her verbal or written questions and demands. 
- The individual is provoked to react in an uncontrolled manner by his/her chiefs or colleagues.

- The individual is not invited to the special occasions or other social activities of the company deliberately.

- Appearance or dressing style of the individual becomes an object of derision.

- All suggestions of the individual about work are refused.

- The individual is paid less than his/her subordinates.

These behaviors are not necessarily to be experienced all at once. Deliberate exhibition of these behaviors and continuous repetition of them, continuation of them for at least 3 to 6 months causes mobbing and as a result, makes the individual have difficulties in the working life and finally the individual becomes estranged from this work. While a behavior contained in this list can create a problem for an individual, the case may not be the same for another individual. And this is directly related to the personality structures of individuals. If a person thinks that; he/she is disturbed and harmed from these behaviors, the behavior firstly turns into a problem and then becomes a mobbing behavior.

We can divide the roles played during the process of mobbing in working life into 3 groups:

-Mobbing practitioners (Harassers)

-Mobbing victims (Victims)

-Mobbing spectators

These roles can change in every single mobbing case. While employees are in the position of harassers in a case, they may be the victim or a spectator in another.

This inferiority complex and feeling of inadequacy in the minds of people are generally reflected on behaviors like patronizing and riding the high horse. And the practitioners of psychological harassment in workplace can be said to be unable to suppress their inferiority complex and feeling of inadequacy no matter why, and direct this behavior particularly at individuals having deprivations that disturb themselves and deal with them by practicing psychological harassments. 
Psychological harasser has a narcissist personality. These people generally disturb other individuals by looking at what they symbolize for them instead of who they are. Envy, jealousy, big goals and challenges are the leading motives of psychological violence. Psychological harassers consider exhibiting harassment behaviors as the only way out since their success in work is compared to that of other employees.

Moreover, it is observed that; these people try to make up for their own deficiencies, fears and mistrusts by humiliating another person, they are intolerant of differences and hypocritical and they think or try to think themselves superior, they are extremely controlling and jealous, and they endeavor to overcome their feeling of inadequacy by ridiculing the hardships of the individual they aim at.

No common ground, that could induce such actions, was found in the characters or pasts of the targets of psychological harassment in the researches conducted about this issue. And it is even deduced that; a considerable majority of victims had superior qualities and they were intelligent, creative, success-oriented and dedicated to their works. Especially, the individuals with advanced creativeness are subjected to intimidation policy by old traditionalist employees who do not want their ground to be shaken, due to the new opinions brought forward by these creative people.

Other common qualities of the targets of psychological harassment are that; they are prone to being introverted in their social lives, they have low self-confidence, and they are honest and good-tempered. This does not only whet the appetite of the individual or the group inclined towards psychological harassment, it also makes the things easier for them. Individuals that can generate new ideas interpret the world with different points of view, does their job very well and even excellently, have positive relations, that are loved by their friends and having strict working principles and values, that are honest and reliable, loyal to organization, independent and creative can be victims of psychological harassment.

"Individuals taking part in psychological harassment as spectators are people like colleagues, chiefs and directors that do not directly get involved in the process, but perceive the process somehow, live through the reflections of such events and sometimes take part in this process" (Tinaz, 2006: 106). 
The unwillingness of the spectators of a psychological harassment case to step into the process encourages the harasser in a sense and enables this individual to continue practicing these actions. The most significant thing that draws the spectators of psychological harassment is the probability that they maybe the next victim. The anxiety and fear they feel set them thinking about whether they should support the victim or not.

\section{Functions of Media}

Before passing on to our study about how news, true case studies about what mobbing is, which processes it includes and the actors of it are covered in media, particularly in printed media; it will be useful to dwell upon the basic functions of media.

Being a communications theorist and a professor of law at Yale University, Lasswell defines three functions of media. Monitoring of environment, making different fractions of society be in a relationship with one another during their reactions with environment and handing down social heritage from generation to generation (Bir ve Sever, 1994, 511).

Monitoring of environment is the primary function, it informs and provides news. The function of monitoring the environment can also lead to various nonfunctionalities. And overemphasis on dangers or threats directed at society may cause panic (Bir ve Sever, 1994, 511).

The second function, associating, is the selection and interpretation of environment-related information. Media generally includes criticism and states how individuals should react to events. Therefore, associating is the editorial and propaganda side of media. The function of associating serves to support social norms and maintain consensus by announcing the out of type things, glorifies selected individuals and provide a status to them and can function in a supervisory way over the government. (Bir ve Sever, 1994, 514)

As a conveyor of culture, media functions as a transmitter of information, values and social norms from a generation to another generation or from the individuals of a society to the new participants of this society. In this way, media improves the base of general experience and works as a social association promoter. (Bir ve Sever, 1994, 515) 
If we turn back to our subject, coverage of mobbing (psychological harassment in workplace) especially in printed media as a news source since 1997 should be assessed within the association function of media. When we look at the content of the mobbing news in the newspapers, mobbing is defined and it is associated with working life and how people react or should react are covered in all these news.

Media, more specifically printed media shapes the agenda of media with the news it reports. One of the study subjects is how printed media transmits the importance of a subject to public. While continuous repetition of the subject, frequent coverage of similar news refer to the importance of the subject, there is also an increase in the public's level of information about the subject. "By means of repetition, signals about the importance of a subject can be conveyed to public, and public agenda is influenced through the accumulating effect of the continuously repeated messages in media related to this issue. When the number of news reported in media about an issue increase over time, when there is more news published about this issue, public is convinced more about the importance of that issue" (Yüksel, 2001; 114).

Matters/events to be covered especially in printed media need to contain some criteria in order to be newsworthy. The first of these is that; subject should be actual, new and easily transmittable. The second is it should be interesting. Things are interesting when they change our niche, basic knowledge and opinions and when they are different from what is accepted. Particularly dramatic events, problems, political frictions and conflicts draw the attention of readers (Schlapp, 1998: 18). The third criterion is the importance of the subject. If an event directly influences economic and cultural life, i.e. if it leads to a change in these fields, it is important. The fourth criterion is the correlation of the subject. Particularly, affinity to the subject generates correlation. Everything that directly affects our lives and feelings creates correlation and therefore valued as newsworthy.

When we assess mobbing news within the frame of all these criteria, the subject is actual and the number of employees experiencing and needing to share this is increasing every passing day. The subject is interesting, because these are events that change our working environment, our basic knowledge and opinions and they are extraordinary. Particularly like the dramatic aspects of the event, depression, exclusion and quitting the job. The subject is important, since 
working life constitutes a considerably big party of our lives. The negative events in working life directly influence social life and social relations. That means, the subject is important as it is basically of concern to individuals and every individual can find something from himself/herself. Finally, mobbing is closely associated with our lives and feelings. Be it the mobbing victim, mobbing practicing tyrant or mobbing spectator, considering the performance of the case and the aftermath, the emotional trait is superior. Because of embodying all the news criteria, mobbing actions are newsworthy and will continue to be so. The important thing is the way these news are presented.

\section{How Mobbing-Related News Appear on Printed Media}

We scanned the newspapers particularly published and distributed on national scale and having relatively wider circulation from internet archives, especially beginning from 1997 where news about Mobbing in working life started to be reported, and we examined the coverage frequency of mobbing news. 3 newspapers giving more space to mobbing news are selected. These newspapers are Hürriyet, Milliyet and Akşam.

\section{Distribution of the News}

The word "mobbing" was scanned in the archives of Hürriyet, Milliyet and Akşam newspapers included in the scope of the study, and the news about this issue were classified by years. While scanning the word "mobbing”, "psychological harassment", "psychological violence" and "emotional harassment" terms were also scanned as its equivalents in Turkish.

The news that we accessed were evaluated according to content analysis method. Principally, 10 criteria were determined and these criteria were inquired in all these news. These criteria are; use of the word "mobbing" in the headline, whether a "mobbing" definition was given in the news, type of news, sex of the mobbing victim, sex of the mobber, the sector where mobbing is experienced, whether an expert opinion is included in the news item, whether mobbing case was brought to trial, if so; its conclusion, and whether photographs are used in the news or not.

The word "mobbing" was scanned in the archives of Hürriyet, Milliyet and Radikal newspapers, which were included in the scope of the study, and the related published news were classified by years. While scanning the word "mobbing", psychological harassment, 
psychological violence and emotional harassment terms were also scanned as the Turkish equivalents.

What we first recognize after scanning the mobbing-related news that have been published since 1997 in Turkish media is that; there is a contradiction in terms. It is seen that; psychological harassment, psychological violence and emotional harassment terms searched in the news in addition to "Mobbing" were used in quite different meanings. These terms were used in their correct meanings when they appeared together with the word "mobbing", and if they appeared apart from "mobbing", they were not having the meaning "psychological harassment, psychological violence and emotional harassment particularly in workplace", that is the subject of our study. Hence, only the news giving place to the term "mobbing" were included within the scope of our study, while evaluating the news related to mobbing.

Media organs being published in national-scale in Turkish printed press and having a certain number of daily circulation were examined. 3 of these newspapers, Hürriyet, Milliyet and Radikal, were observed to report news that could make a sense in number. The numbers of mobbing-related news in the other newspapers are between 5-10 starting from 1997.

The number of news published in 3 newspapers by years

\begin{tabular}{|l|l|l|l|}
\hline & Hürriyet & Milliyet & Radikal \\
\hline 1997 & 1 & - & - \\
\hline 1998 & - & - & - \\
\hline 1999 & - & - & - \\
\hline 2000 & 1 & - & - \\
\hline 2001 & - & - & - \\
\hline 2002 & 1 & - & - \\
\hline 2003 & - & 1 & - \\
\hline 2004 & - & - & - \\
\hline 2005 & 1 & 1 & - \\
\hline 2006 & 2 & 3 & 1 \\
\hline 2007 & 2 & - & 1 \\
\hline
\end{tabular}




\begin{tabular}{|l|l|l|l|}
\hline 2008 & 4 & 6 & 8 \\
\hline 2009 & 10 & 3 & 4 \\
\hline Total & 22 & 14 & 14 \\
\hline
\end{tabular}

Table 1: The number of news published in 3 newspapers by years

The statistical distribution of the news published in the 3 newspapers that we've included in our study is given in table 1. According to the table, the most news (22 news) were published in Hürriyet Newspaper, then Milliyet and Radikal newspapers published equal number of mobbing-related news (14 news).

Considering their distribution by years, we see that; the first news in Hürriyet Newspaper was published in 1997, and there was an increase in the number of news especially after the year 2006. It was in 2009 that the most news related to this issue have been published in Hürriyet Newspaper. Hürriyet is the newspaper that reported a news about this issue and gave place to the most number of news. When we look at Milliyet Newspaper, mobbing news started to be reported since 2003 and the most news were published in 2008. And Radikal Newspaper reported mobbing-related news from 2006 onwards, and particularly in 2008, more news were published in quantitative terms compared to the other newspapers.

It is seen that; these 3 newspapers giving the maximum place to mobbing-related news have particularly increased the number of such news in recent years, particularly during 2008-2009. While there were only 18 news published in these 3 newspapers in 2008, this number increased to 17 in the year 2009. In view of the date the study was carried out, we should keep in mind that; the year 2009 is not over yet.

Hürriyet Newspapers started to report the first mobbing-related news in 1997. While Milliyet newspaper published mobbing news for the first time in 2003, Radikal newspaper took an interest in the subject from 2006 onwards, and included this subject in its news.

In the year 2008, when mobbing was included in Turkish Penal Code, there was an increase in the number of news published in the press.

Distribution of the news individually for every newspaper is given below: 
Table 2: Distribution of the News in Hürriyet Newspaper

\begin{tabular}{|c|c|c|c|c|c|c|c|c|c|c|}
\hline News & $\begin{array}{l}\text { Use of the } \\
\text { word } \\
\text { "mobbing" } \\
\text { in the } \\
\text { headline }\end{array}$ & $\begin{array}{l}\text { Definition of } \\
\text { mobbing in } \\
\text { the news }\end{array}$ & $\begin{array}{l}\text { Type of } \\
\text { News }\end{array}$ & $\begin{array}{l}\text { Mobbing } \\
\text { Victim } \\
\text { Female/ } \\
\text { Male }\end{array}$ & $\begin{array}{l}\text { Mobber } \\
\text { Female/Male }\end{array}$ & $\begin{array}{l}\text { The sector } \\
\text { where mobbing } \\
\text { is experienced }\end{array}$ & $\begin{array}{l}\text { Expert } \\
\text { opinion } \\
\text { was } \\
\text { included in } \\
\text { the news }\end{array}$ & $\begin{array}{l}\text { Mobbing case } \\
\text { was brought to } \\
\text { trial }\end{array}$ & Trial result & $\begin{array}{l}\text { Photo used } \\
\text { in the news }\end{array}$ \\
\hline N1 & Yes & Yes & Informative & - & - & - & No & - & - & No \\
\hline $\mathrm{N} 2$ & Yes & Yes & Informative & - & - & - & Yes & - & - & No \\
\hline N3 & Yes & Yes & Informative & - & - & - & Yes & - & - & No \\
\hline N4 & No & Yes & Informative & - & - & - & Yes & - & - & Yes \\
\hline N5 & No & Yes & Informative & - & - & - & Yes & - & - & No \\
\hline N6 & No & Yes & True story & Female & Male & State & Yes & Yes & Positive & Yes \\
\hline N7 & No & Yes & Informative & - & - & - & Yes & - & - & Yes \\
\hline N8 & No & No & True story & Female & Male & State & No & No & - & No \\
\hline N9 & No & No & True story & Male & Male & State & No & Yes & Ongoing & No \\
\hline N10 & No & No & True story & Male & Male & State & No & Yes & Ongoing & No \\
\hline N11 & No & No & True story & Male & Male & State & No & Yes & Ongoing & No \\
\hline N12 & No & Yes & Informative & - & - & - & Yes & - & - & Yes \\
\hline N13 & No & No & True story & Female & Female/Male & State & No & Yes & Ongoing & No \\
\hline
\end{tabular}




\section{Online Journal of Communication and Media Technologies}

\begin{tabular}{|c|c|c|c|c|c|c|c|c|c|c|}
\hline N14 & No & Yes & Informative & - & - & - & Yes & - & - & Yes \\
\hline N15 & Yes & Yes & True story & Male & Female/Male & Private & No & Yes & Ongoing & No \\
\hline N16 & Yes & Yes & True story & Male & Female/Male & Private & No & Yes & Ongoing & Yes \\
\hline N17 & Yes & No & True story & Male & Male & Private & No & Yes & Ongoing & Yes \\
\hline N18 & Yes & Yes & True story & Male & Male & State & Yes & Yes & Positive & Yes \\
\hline N19 & No & Yes & True story & Female & Female & State & No & Yes & Ongoing & No \\
\hline $\mathrm{N} 20$ & No & No & True story & Male & Male & State & No & Yes & Positive & Yes \\
\hline $\mathrm{N} 21$ & Yes & Yes & Informative & - & - & - & No & - & - & Yes \\
\hline $\mathrm{N} 22$ & No & Yes & Informative & - & - & - & No & - & - & Yes \\
\hline
\end{tabular}


A total of 22 news published in Hürriyet Newspaper are evaluated under 10 topics in Table 2.

The firs consideration was, whether the word mobbing was used in the headlines of the news in Hürriyet Newspaper. The word "mobbing" was used in 8 headlines and 14 of them did not include this word.

"Mobbing" was defined in 15 news and 7 of them did not define mobbing. Looking at the type of news, 10 of them were informative and 12 were based on a true story. Informative news dwelled upon the concept of mobbing and it was attempted to explain all the aspects of mobbing and draw attention to this issue. But in the news based on true stories, mobbing victims, the difficulties experiences and the process were described.

When we examine 12 news from Hürriyet Newspaper that covered true stories, 4 of the victims in these news were female and 8 were men. When we look at the sex of the mobbers in these 12 reports, the result is as follows: 8 of the mobbers were male, 1 was female and 3 of them were female and male in company.

Looking at the sectors where mobbing cases are experienced in the news reporting true stories, it was found out that; 9 of them were experienced in state sector and 3 of them happened in private sector.

Taking a look at the presence of expert opinion in the whole 22 news from Hürriyet Newspaper, 13 of the news did not have an expert opinion, and 9 of them included opinions from various experts. Compared with the other news, we see that; mobbing-related news have more definitions, expert opinions, and the primary objective is giving information in such news.

Mobbing also has a legal aspect. Therefore, particularly in the news giving place to true stories, it is also important whether the case was brought to trial and how it was concluded. In 11 of this news, victims took legal action to claim their rights. Only 1 victim did not go to law. It was seen that; the trials of 8 victims out of 11 , who resorted to legal remedy, were continuing. And 3 of the victims in search of legal remedy had positive results. The appearance of "mobbing" in Turkish Penal Code from December 2008 onwards led to an 
increase in the attention to this issue, and made mobbing victims to turn towards judicial process.

And finally the use of photos in the news was examined. 11 of the 22 mobbing-related news in Hürriyet Newspaper included photos and 11 of them not. While 4 of the photos used belonged to victims, 7 of them were photos showing a conflictual working environment.

Hürriyet Newspaper is the newspaper that has the widest coverage of mobbing news, and it is understood that; this newspaper aims to improve the knowledge of public about this issue with these news. 
Table 3: Distribution of the News in Milliyet Newspaper

\begin{tabular}{|c|c|c|c|c|c|c|c|c|c|c|}
\hline News & $\begin{array}{l}\text { Use of the } \\
\text { word } \\
\text { "mobbing" } \\
\text { in the } \\
\text { headline }\end{array}$ & $\begin{array}{l}\text { Definition } \\
\text { of mobbing } \\
\text { in the news }\end{array}$ & $\begin{array}{l}\text { Type of } \\
\text { News }\end{array}$ & $\begin{array}{l}\text { Mobbing } \\
\text { Victim } \\
\text { Female/ } \\
\text { Male }\end{array}$ & $\begin{array}{l}\text { Mobber } \\
\text { Female/Mal } \\
\text { e }\end{array}$ & $\begin{array}{l}\text { The sector } \\
\text { where } \\
\text { mobbing is } \\
\text { experience } \\
\text { d }\end{array}$ & $\begin{array}{l}\text { Expert } \\
\text { opinion was } \\
\text { included in } \\
\text { the news }\end{array}$ & $\begin{array}{l}\text { Mobbing } \\
\text { case was } \\
\text { brought to } \\
\text { trial }\end{array}$ & Trial result & $\begin{array}{l}\text { Photo } \\
\text { used in } \\
\text { the news }\end{array}$ \\
\hline N1 & No & No & True story & Male & Male & State & No & Yes & Ongoing & No \\
\hline $\mathrm{N} 2$ & No & Yes & True story & Female & Female & State & No & Yes & Ongoing & No \\
\hline N3 & No & Yes & Informative & - & - & - & Yes & - & - & $\mathrm{No}$ \\
\hline N4 & Yes & Yes & Informative & - & - & - & Yes & - & - & Yes \\
\hline N5 & No & Yes & Informative & - & - & - & Yes & - & - & No \\
\hline N6 & No & Yes & Informative & - & - & - & Yes & - & - & No \\
\hline N7 & No & Yes & Informative & - & - & - & Yes & - & - & No \\
\hline N8 & No & Yes & Informative & - & - & - & No & - & - & No \\
\hline N9 & No & Yes & True story & Male & Male & State & No & Yes & Ongoing & No \\
\hline N10 & No & Yes & True story & Female & Male & State & Yes & Yes & Positive & No \\
\hline N11 & Yes & Yes & Informative & - & - & - & Yes & - & - & No \\
\hline N12 & No & Yes & Informative & - & - & - & Yes & - & - & No \\
\hline N13 & Yes & Yes & Informative & - & - & - & Yes & - & - & No \\
\hline N14 & No & Yes & Informative & - & - & - & Yes & - & - & No \\
\hline
\end{tabular}


In Milliyet Newspaper, where we examined "Mobbing"-related news, there were total 14 news.

While the word "mobbing" was used in 2 of these 14 news, 12 of them did not use it.

13 out of 14 news reported in Milliyet Newspaper defined what "mobbing" is, but 1 report did not include a definition. It is an interesting result that a great majority of the news defines mobbing.

While 10 out of 14 news were informative, true stories were mentioned in 4 news. It is possible to say that; mobbing news in Milliyet Newspaper are particularly published to perform the informative function.

Looking at the true stories in these 4 news, the actors of the events in 2 are male and 2 are female. 3 of the mobbers in these events are male and 1 of them is female.

In all the 4 news involving true mobbing events, the mobbing events were experiences in state sector.

10 out of 14 news reported in Milliyet newspaper gave place to expert opinion and the reports were supported by expert opinions. But, the remaining 4 did not include any expert opinion.

All the 4 news including these true stories were brought to trial. While 3 of the cases were continuing, 1 case resulted in favor of the mobbing victim.

Only a single news report published in the newspaper included photos.

In the grand perspective of the news published in Milliyet newspaper, it is possible to say that; informative news were made, mobbing was tried to be explained, definitions were made, expert opinions were frequently included and photos were used in the news predominantly. 
Table 4: Distribution of the News in Radikal Newspaper

\begin{tabular}{|c|c|c|c|c|c|c|c|c|c|c|}
\hline News & $\begin{array}{l}\text { Use of the } \\
\text { word } \\
\text { "mobbing" } \\
\text { in the } \\
\text { headline }\end{array}$ & $\begin{array}{l}\text { Definition } \\
\text { of mobbing } \\
\text { in the news }\end{array}$ & $\begin{array}{l}\text { Type of } \\
\text { News }\end{array}$ & $\begin{array}{l}\text { Mobbing } \\
\text { Victim } \\
\text { Female/ } \\
\text { Male }\end{array}$ & $\begin{array}{l}\text { Mobber } \\
\text { Female/Mal } \\
\text { e }\end{array}$ & $\begin{array}{l}\text { The sector } \\
\text { where } \\
\text { mobbing is } \\
\text { experience } \\
\text { d }\end{array}$ & $\begin{array}{l}\text { Expert } \\
\text { opinion was } \\
\text { included in } \\
\text { the news }\end{array}$ & $\begin{array}{l}\text { Mobbing } \\
\text { case was } \\
\text { brought to } \\
\text { trial }\end{array}$ & Trial result & $\begin{array}{l}\text { Photo } \\
\text { used in } \\
\text { the news }\end{array}$ \\
\hline N1 & Yes & Yes & Informative & - & - & - & Yes & - & - & No \\
\hline N2 & Yes & Yes & Informative & - & - & - & Yes & - & - & No \\
\hline N3 & No & Yes & True story & Female & Female & State & No & Yes & Ongoing & No \\
\hline N4 & No & No & True story & Female & Female & State & No & Yes & Ongoing & No \\
\hline N5 & Yes & Yes & Informative & - & - & - & Yes & - & - & No \\
\hline N6 & Yes & Yes & True story & Female & Male & State & No & Yes & Positive & Yes \\
\hline N7 & Yes & Yes & Informative & - & - & - & No & - & - & No \\
\hline N8 & No & Yes & Informative & - & - & - & No & - & - & No \\
\hline N9 & No & Yes & True story & Male & Male & State & No & Yes & Ongoing & No \\
\hline N10 & Yes & Yes & Informative & - & - & - & Yes & - & - & No \\
\hline N11 & Yes & Yes & True story & Male & Male & State & No & Yes & Ongoing & No \\
\hline N12 & Yes & No & True story & Male & Male & State & No & Yes & Ongoing & No \\
\hline N13 & Yes & Yes & True story & Male & Male & Private & No & Yes & Negative & No \\
\hline N14 & No & Yes & True story & Female & Male & State & No & Yes & Positive & No \\
\hline
\end{tabular}

(C) Online Journal of Communication and Media Technologies 
Finally, "mobbing" news in Radikal newspaper were examined. There were 14 news in Radikal newspaper like in Milliyet newspaper. Looking at the headlines, 9 of them included the word "mobbing" and 5 of them did not so.

12 out of 14 news included a "mobbing" definition, while no definition was found in 2. While 6 of the news were informative, 8 of them were presented by taking true stories as the subject.

4 of the victims of the experienced true stories are female and the remaining 4 are male. When we consider the mobbers, 6 of them are male and 2 female.

Taking a look at the distribution of the sectors where mobbing was experienced, it is evident that; 7 of them happened in state sector and 1 happened in private sector. Looking at the news from a broader perspective, we can see that; 4 out of 14 news gave place to expert opinion and 10 of them did not so.

All of the news reporting the true stories were brought to trial. 2 out of 8 cases were concluded in favor of the victim and 1 of them was concluded against the victim. And 5 cases are still continuing.

Only 1 out of 14 news published in Radikal newspaper made use of a photograph.

Most of the 14 news published in Radikal Newspaper took true stories as the subject and they are informative.

\section{Conclusion}

Mobbing has particularly become a study subject in Turkey in the last 7-8 years. Mobbing, which is the study subject of disciplines like labor economics, organizational communication, human resources and communication, has started to gain more attention with the published reference books, statements presented in conferences and articles published in periodicals.

Mobbing (psychological harassment and intimidation at workplace), which has entered the laws of many countries, has also entered Turkish judicial system. In the amended version of 
the Code of Obligations Draft, that passed from Justice Commission and put into effect following the approval of the Parliament in December 25, 2008, it is stipulated that; employer is also obliged to take measures against psychological harassment.

From now on, a employee subjected to psychological harassment has many legal remedies to apply to both within the scope of Turkish Civil Code and also Labor Law. Apart from all these, there are also some remedies that could be followed by officers subjected to psychological harassment within the scope of administrative law. The employee is required to collect some evidence and more importantly not to be defeated by the harassment he/she is subjected to and he/she must not be reluctant to struggle with this in order to appeal to legal remedies. The role of employer within this scope is being responsive to the issue, taking measures to ensure the employees working within the structure of the company do not become a psychological harassment victim, and to form mechanisms where victimized employees can receive aid. Accordingly, it is necessary to inform and raise awareness of public at large and particularly employees and employers, and to carry out studies aimed at removing the obstacles to taking legal action against such harassments.

However, this concept is still so fresh in Turkey. Though the Turkish equivalent of mobbing is not completely agreed upon, mobbing concept has directly started to appear in printed media. Many individuals are not aware that; they suffer from mobbing. Therefore, media has a great mission in this respect. Increasing the recognition level of mobbing is the biggest power in preventing the spread of mobbing. With the appearance of mobbing in the laws as a criminal act, the number of the related news in the media has shown an increase. The most important function of media is to inform and raise awareness of public. As the number of news about the term mobbing, which has an old history, but is defined only recently, more individuals could become aware of this subject and make sense of what they live or witness and maybe claim their rights by taking legal action.

Since the subject is not completely known yet, 5 life coaches, 2 psychologists and 1 lawyer united and founded Mobbing Information and Research Support Center on April 22, 2009. This center offers free consultancy and support service to mobbing victims. 20 people have called the center up to now, and all of them are white-collar, well-educated women working in big companies. 
Our study particularly aimed to reveal how mobbing is reported as news in Turkish printed media. As a result of our analysis, mobbing was found to be reported as news in printed media since 1997, but recently, in the years 2008 and 2009, there has been an increase in the number of news related to this issue, particularly with the appearance of mobbing in the laws. It was observed that; most of the mobbing-related news were informative and described and explained the subject and mostly, mobbing was made public in the news content.

Another type of news was the ones where true stories were narrated. These news also contained definitions of mobbing. When these news were analyzed, it was seen that; there were a total 24 true story adaptations in these 3 newspapers. 10 of the victims are female and 14 are male in these news. Considering the sex of the mobbers, 7 of them are female and 17 male. We can gather by looking at these rates that; both men and women are subjected to mobbing in Turkey, but there is a significant statistical superiority of men as mobbers. From the 3 newspapers that we analyzed, Hürriyet published the most news about this issue. Radikal Newspapers is the one that included true stories most with respect to the reported news. Milliyet newspaper predominantly gave informative news. When we analyze the news that include real stories, it is seen that; most of these events happened in state sector. The reason is that; senior management staff of governmental agencies change as the governments (political power) change in Turkey. With these changes, every management wants to establish their own sub-staffs and therefore, involuntary changes of position happen among employees in many organizations. It is seen from the news reflected in the press that; it's becoming common to consider these negative events as mobbing.

Almost all of the true mobbing events reflected in the press were brought to trial. Not may cases are concluded yet, and many trial processes are still going on. And most of the concluded trials ended in favor of victims. Having wide media coverage of news that particularly include trials that are concluded in favor of mobbing victims, will encourage mobbing victims with respect to claiming their rights.

In conclusion, mobbing event is newsworthy since it is actual and is of concern to many people. It is evident that; the news related to this subject are increasing and the number is expected to increase more. The way the news are published in Turkish press is in the form of 
drawing attention to the subject, increasing the recognition of the subject, directing the individual to question what he/she has lived or witnessed by including true case studies and informing by showing the ways to eliminate unjust treatment. We think that; the more coverage of mobbing in the press will lead to more recognition about this subject.

\section{References}

Bir, A.A. Sever, S. (1994), İletişim Kuramları, Anadolu Üniversitesi Yayınları, Eskişehir.

Çobanoğlu, Ş. (2005). Mobbing/İş Yerinde Duygusal Saldırı ve Mücadele Yöntemleri. İstanbul: Timaş Yayıncılık.

Davenport, N., Schwartz, R.D,, \&Elliott, G.P. (2003). Mobbing: İşyerlerinde Duygusal Taciz. Osman Cem Önortay (Çeviren), İstanbul: Sistem Yayıncılık. (2003).

Dökmen, Ü. (2008). Sanatta ve Günlük Yaşamda İletişim Çatışmaları ve Empati. İstanbul: Remzi Kitapevi.

Hermann SCHLAPP (1999). Gazeteciliğe Giriş, Çev: Işık Aygün, Luzern Medya Eğitim Merkezi Yayınları.

Güngör, M. (2008). Çalışma Hayatında Psikolojik Taciz. İstanbul: Derin Yayınları.

Köse, H. (2006). Örgüt içi İletişimde Negatif Bir Olgu: Psikolojik Yıldırma ve Sistemli Bir Ötekileştirme Süreci Olarak Mobbing, (2,10,2008), http://www.if.kocaeli.edu.tr

Leymann, H. (1990). Mobbing and Psychological Terror at Workplaces. Violence and Victims, 5, 119-126.

Leymann, H. (1996). The Content and Development of Mobbing at Work, European Journal of Work and Organizational Psychology, 5 165-184.

Namie, G. \& Namie, R. (2000). The Bully at Work, Illinois: Sourcebooks, Inc.

Süleyman İrvan, (2000), "Metin Çözümlemelerinde Yöntem Sorunu”, Medya ve Kültür, (3-5

Mayıs 2000, 1. Ulusal İletişim Sempozyumu Bildirileri,) Ankara Gazi Üniversitesi İletişim Dergisi.

Şimşek, M.Ş., Akgemci, T. \& Çelik, A. (2001). Davranış Bilimlerine Giriş ve Örgütlerde Davranış. Ankara: Nobel Yayınları.

Tinaz, P. (2006). İşyerinde Psikolojik Taciz, İstanbul: Beta Yayınevi.

Tutar, H. (2004). İşyerlerinde Psikolojik Şiddet. Ankara: Platin Yayıncılık.

Yüksel, E. (2001). Medyanın Gücü, Çizgi Kitapevi, Konya. 